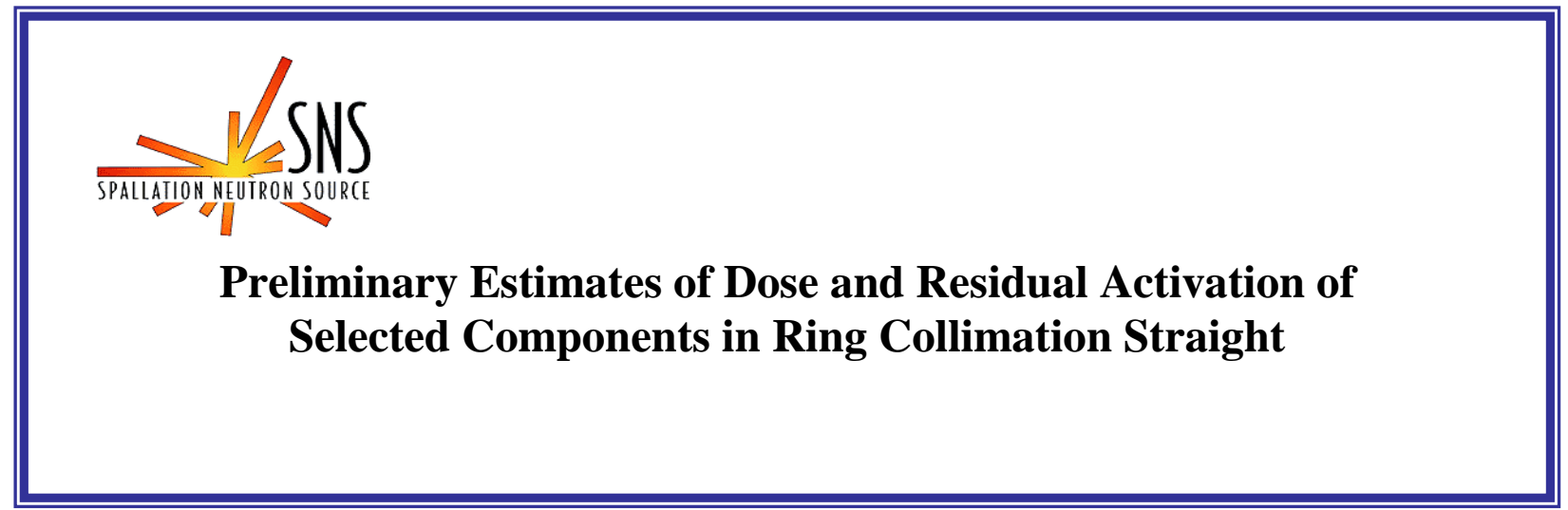

BNL/SNS TECHNICAL NOTE

NO. 077

H. Ludewig, J. Walker*, N. Catalan-Lasheras, N. Simos,

A. Mallen, J. Wei, and M. Todosow

June 6, 2000

COLLIDER-ACCELERATOR DEPARTMENT

BROOKHAVEN NATIONAL LABORATORY

UPTON, NEW YORK 11973 


\title{
PRELIMINARY ESTIMATES OF DOSE AND RESIDUAL ACTIVATION OF SELECTED COMPONENTS IN RING COLLIMATION STRAIGHT
}

\author{
H. Ludewig, J. Walker*, N. Catalan-Lasheras, N. Simos, A. Mallen, J. Wei, and M. Todosow. \\ Brookhaven National Laboratory, Upton, New York, USA. 11973.
}

\section{Introduction}

In this report an estimate of the dose to the following components in the collimation straight of the ring will be made:

1) Windings of the quadru-pole magnets,

2) Windings of a typical corrector magnet,

3) Cable located along the inside tunnel wall, and

4) Outer edge of the earth berm covering the tunnel.

In addition, to the above dose estimates the residual activation of the following components in the collimation straight following machine operation and shutdown, will be made:

1) Tunnel cooling water,

2) Tunnel air,

3) Cooling water for the collimators, and

4) Windings and pole pieces of a typical quadru-pole.

The estimate of activation will be made primarily to determine the concentration of long lived isotopes, and in the case of water and air the concentration of tritium will be of particular interest.

In all the above estimates the machine is assumed to operate at an average power of $2 \mathrm{MW}$, with a proton energy of $1 \mathrm{GeV}$, and a loss of 0.001 . In the case of the dose estimates it was assumed that the loss occurs at all three collimator locations i.e. 0.001 at the first, 0.001 at the second, and finally 0.001 at the third. If the loss profile is different the dose components due to losses at the various collimators can be added in different proportions. In the case of the residual activation estimates the loss was simulated only at the first collimator. A residual activation estimate corresponding to a more realistic loss profile will be carried out when the losses are more clearly defined. In these estimates the entire collimation straight will be simulated, including the primary scraper/collimator, the other two collimators, two doublets (consisting of two quadru-poles of unequal length), two quadru-poles at either end, and one corrector magnet positioned in the most vulnerable position (between the first doublet and the scraper/collimator). Four cable trays are positioned along the inner wall at a variety of elevations above the vacuum chamber. Two tunnel cooling water lines are considered, one along the inside wall of the tunnel, and the second along the outside wall below the crane.

In the following sections the model and method of analysis will be described, dose estimates will 
be presented and finally the residual activation results will be presented.

\section{Methods and Modeling}

The above estimates of dose and residual activation are both based on the MCNP family of codes. In the case of the dose estimate the MCNPX [1] code was used. This code uses the combinatorial representation of geometry, in the same way all previous MCNP based codes have used it, and the geometry descriptions are inter-changeable among all codes. However, MCNPX has a high energy transport section available, which allows the same physical phenomena as the LAHET code [2]. The primary proton $(1 \mathrm{GeV})$, and all the resulting secondary particles can be followed, edited and tallied in any desirable manner over the entire energy range of interest.

In order to estimate the dose in a particular cell the energy deposition was estimated in that cell (F6:n,p,h tally in MCNPX) in MeV/g-proton. In order to convert $\mathrm{MeV} / \mathrm{g}$ to rad it is recognized that $1 \mathrm{rad}=100 \mathrm{erg} / \mathrm{g}$, and that there are $1.602 \times 10^{-6} \mathrm{ergs} / \mathrm{MeV}$. Thus the F6 tally was multiplied by $1.602 \times 10^{-8}$ to result in $\mathrm{rad} /$ proton. This value was them further multiplied by the loss in protons/s $\left(1.243 \times 10^{13}\right)$, seconds/hr (3600), and $\mathrm{mrad} / \mathrm{rad}(1000)$. The total multiplicative factor for the F6 tally is thus $7.168675 \times 10^{11}$ to result in a dose of $\mathrm{mrad} / \mathrm{hr}$ in a particular cell of interest.

Due to the need to link to other codes the residual activation estimate was made using the LAHET codes for particles above $20 \mathrm{MeV}$; and MCNP [3] for particles below $20 \mathrm{MeV}$. In addition, a suitably modified version of the ORIGEN [4] code was used to estimate the buildup of spallation products during machine operation, and their decay following shutdown. In this calculational string the spallation product mass distribution is determined by the LAHET code, the averaged neutron energy spectrum in the cell of interest is determined by MCNP, and these two pieces of information are used to determine the appropriate nuclear cross section data and inventory of spallation products used in the modified ORIGEN code for the estimated build-up and decay of radioactive nuclides in the cell while the machine is operating and following shutdown. In this case the machine loss rate in protons/s $\left(1.243 \times 10^{13}\right.$ protons/s lost on primary scraper) is used to determine the neutron flux, and is thus the connection to the overall machine power. In addition assumptions must be made regarding the operating time of the machine. In all these estimates it was assumed that the machine operates at full power for 180 days. In order to determine the residual activation for different times it is reasonable to scale the activity by the number of full power days. The two calculational sequences described above are shown in Fig. 1. The upper sequence represents the determination of dose using MCNPX, and the lower sequence represents the determination of residual activation. It is seen that the lower sequence involves several codes, and an extensive nuclear data library.

The actual layout of the lattice in the collimation straight of the ring is shown in Fig. 2. From the figure it is seen that the straignt section is $30 \mathrm{~m}$ in length, with three collimators, two sets of doublets, two quadru-poles one at each end, and two corrector magnets. The distance between the quadru-poles and the two collimators at each end is approximately $1.5 \mathrm{~m}$, and the distance from the primary scraper/collimator to the corrector magnet is approximately $0.5 \mathrm{~m}$. This short distance between magnets and high loss locations in the ring raises the concern of radiation induced damage to these components, in particular the insulation of the magnet windings. In 
addition, the potential radiation damage to the insulation of the cables located in the cable trays attached to the inner wall above the collimators will be of concern. There is a comparatively long straight section between the second collimator and the second doublet $(\sim 12 \mathrm{~m}$.) Which ensures that these magnets should not be subject to the same environment as the first doublet.

The primary scraper/collimator consists of a $0.55 \mathrm{~cm}$ thick platinum scraper which protrudes into the halo, and perturbs the beam orbit sufficiently that the particles are deflected into one of the secondary collimators. It has been found that the scraper location must be surrounded by a substantial structure to absorb the bulk of the secondary particles generated in the scraper due to nuclear interactions, and tertiary particles generated in the structure. A fraction of this particle shower leaks out, and irradiates the down stream magnets. In these estimates it was assumed that the vacuum chamber remains unchanged in size, thus resulting in a substantial leakage path for secondary particles leaving the scraper. The second and third collimators are restrictions in the vacuum chamber and follow the beam profile at that particular location.

\section{Dose Estimates}

Estimates of the dose were carried out for selected magnet cells for each magnet, cable located in trays closest to the collimators and the outer cells of the earth berm.

\section{Magnets}

Dose estimates were carried out for the section of the magnet windings protruding from the magnet frame. Thus there are four cells on each side of a quadru-pole magnet. This is illustrated in Figs. 3 and 4, which show a cross section through a typical quadru-pole and the location of the four cells of interest. The MCNP model is illustrated in Fig 5, which shows the three collimators, two doublets, two quadru-poles and one corrector. The corrector is the one located closest to the primary scraper/collimator and is expected to experience a high dose. The estimated doses for the various magnets are shown on table 1 for the loss pattern described above. Briefly, it was assumed that the same loss is experienced at each collimator. The assumed loss is 0.001 of the primary beam at full power. The resulting dose is the sum of the dose estimated for losses at each collimator. The first quadru-pole experiences a comparatively low dose, approximately $3 \mathrm{rad} / \mathrm{hr}$ on the side opposite the collimator, and approximately $50 \mathrm{rad} / \mathrm{hr}$ on the side facing the collimator. The corrector magnet volumes experience doses varying from $2000 \mathrm{rad} / \mathrm{hr}-4000$ $\mathrm{rad} / \mathrm{hr}$ depending on location, and the attached doublet experience doses between $4000 \mathrm{rad} / \mathrm{hr}$ $5000 \mathrm{rad} / \mathrm{hr}$. This combination experiences the highest dose, since it is comparatively close to the primary scraper/collimator. Cells in the second doublet have doses which are between $150 \mathrm{rad} / \mathrm{hr}$ - $250 \mathrm{rad} / \mathrm{hr}$, and finally cells in the last quadru-pole experience doses between $515 \mathrm{rad} / \mathrm{hr}-620$ $\mathrm{rad} / \mathrm{hr}$.

The life expectance of kapton (proposed insulation for the magnet windings) in a radiation field is between $5 \times 10^{8} \mathrm{rad}-10^{9} \mathrm{rad}$, thus at the highest dose rate the magnet insulation should last approximately $10^{5} \mathrm{hrs}-2 \times 10^{5} \mathrm{hrs}$. If it assumed that the machine will operate for three quarters of a year it should be expected that the first doublet will have to be changed at least once in the machine lifetime - assuming a thirty year life. 


\section{Cable}

The cable tray is assumed to be located along the inside wall of the ring, at an elevation just above the height of the collimator diameter ( $1 \mathrm{~m}$ above the vacuum chamber centerline). This arrangement is illustrated in Fig.6, which shows four cable trays fixed to the inside tunnel wall above the collimators. The cell numbers refer to the lower cable tray, closest to the collimators and vacuum chamber, and their ordered increases with distance from the entrance to the collimation straight of the ring. As with the magnets the final dose was assumed to be due to an equal loss at each collimator. The results shown in Table 1 show that the dose varies axially along the tunnel, with the highest dose occurring just downstream of the primary scraper/collimator. It is seen that the dose varies between $125 \mathrm{rad} / \mathrm{hr}-1525 \mathrm{rad} / \mathrm{hr}$. Although this dose is lower than that experienced by the magnet windings, the insulation on cables is generally not as resistant to radiation damage as the insulation on magnet windings. If the insulation can withstand between $10^{8} \mathrm{rad}-5 \times 10^{8} \mathrm{rad}$ the cables should last approximately $7 \times 10^{4} \mathrm{hrs}-4 \times 10^{5} \mathrm{hrs}$. This lifetime estimate would suggest that at least a section of the cable might have to be replaced during the lifetime of the machine.

\section{Earth berm and tunnel air}

The dose estimated in the earth berm and selected tunnel air cells, as a result of losses at the collimators is also shown in Table 1. The earth berm thickness assumed in this analysis is $5 \mathrm{~m}$, and the composition is characteristic of soil at ORNL (same as soil used in LINAC earth berm calculation). The cells being considered for this estimate are shown on Fig. 6. In the case of the earth berm only those cells located on the outside of the berm on either side of the tunnel were considered. The distribution of dose within the berm was not estimated. The results indicate that there is a pronounced variation along the outside of the berm, both on the inside and outside of the tunnel. The dose is quite low at the entrance cells $(\sim .05 \mathrm{mrad} / \mathrm{hr})$, and then increases to approximately $4.2 \mathrm{mrad} / \mathrm{hr}$ just downstream of the primary scraper/collimator location, and then drops down again. However, at the exit of the collimation straight the dose is still $\sim 0.8 \mathrm{mrad} / \mathrm{hr}$. Since, the losses along the collimation straight are expected to be higher than the nominally assumed $1 \mathrm{~W} / \mathrm{m}$ a thicker earth berm should be investigated for this region.

The dose to the tunnel air was estimated for the five cells shown on Fig. 7. The dose peaks downstream of the scraper/collimator, with a peak value of $\sim 500 \mathrm{rad} / \mathrm{hr}$.

It should be noted that the above dose estimates were based on the nominal loss rate assumed for collimators ( 0.001 of the full power operating beam current). If the losses are higher for any reason, then the doses will increase proportionally, and the conclusions regarding component lifetime should be modified accordingly.

\section{Residual Activity}

An estimate was made of the residual activity in the collimator cooling water, tunnel cooling water, selected magnet cells, and the tunnel atmosphere. These estimates were made assuming that the losses are confined to the primary scraper/collimator, additional activity due to other 
losses have not been estimated at this time. However, based on the above results, losses at this location are responsible for a significant fraction of the dose to the magnets, cables, and earth berm, and it is thus expected that the estimates of activity based on losses at this location should capture a significant fraction of their activity. The primary purpose of this preliminary estimate is to determine the residual activation due to nuclides which survive beyond approximately 4 hours following machine shutdown. In all cases it is assumed that the machine operates at full power (2 MW) for 180 days, and then the residual activation is determined immediately following shutdown, $4 \mathrm{hrs}$ later, and at a selection of times beyond that period.

\section{Collimator cooling water.}

Activation of the cooling water in the four major volumes in the primary collimator was estimated for the operating cycle summarized above. Two of these volumes are situated on either side of the scraper, and thus experience the scattered primary proton and secondary proton and neutron fluxes. The other two volumes are situated at either end of the collimator structure and thus are exposed primarily to neutron fluxes, the protons being stopped by the collimator.

The results of these estimates in curies are shown on Tables 2 - 4. The results on Table 2 show that the cells closest to the scraper have the highest residual activity, which dies off quite rapidly as the shorter lived isotopes decay. Immediately following shutdown the activity is dominated by ${ }^{15} \mathrm{O},{ }^{16} \mathrm{~N},{ }^{11} \mathrm{C}$, and ${ }^{12} \mathrm{~B}$, all of which have a short half-life. Following 4 hrs. the dominant nuclides are ${ }^{7} \mathrm{Be}$, and ${ }^{14} \mathrm{C}$, in selected cases ${ }^{3} \mathrm{H}$ and ${ }^{10} \mathrm{Be}$ also play a role. ${ }^{3} \mathrm{H}$ is generated in all cells The resulting gamma-ray source is shown in Table 3. The source essentially follows the activity variation, being highest immediately following shutdown, and decreasing precipitously following $4 \mathrm{hrs}$ after shutdown. After one day the source remains largely constant, being caused primarily by the decay of ${ }^{7} \mathrm{Be}$ and ${ }^{14} \mathrm{C}$. A detail accounting of the activity due to ${ }^{3} \mathrm{H},{ }^{7} \mathrm{Be},{ }^{10} \mathrm{Be}$, and ${ }^{14} \mathrm{C}$ is shown on Table 4. It is seen that the production of these isotopes occurs in the volumes closest to the scraper. The total activity of these nuclides in these volumes are:

$\begin{array}{ll}\text { Isotope Activity (Curies) } \\ \text { Tritium } & 2.6 \times 10^{-8} \\ \text { Beryllium-7 } & 6.1 \times 10^{-2} \\ \text { Carbon-7 } & 2.2 \times 10^{-5}\end{array}$

\section{Selected magnet volumes in first Doublet}

The quadru-pole magnets and the associated corrector magnet experience the highest doses of any component in the collimation straight of the ring. Based on this data it was decided to estimate the residual activity in that portion of the windings that protrude beyond the magnet frame. This should be considered an initial estimate, a more detailed analysis will be used to estimate the residual dose which can be expected in the event that such a magnet needs to be changed. The residual activity in Curies is shown in Table 2. It is seen that the initial activity, immediately following shutdown is less than one Curie, and then it drops off by approximately a factor of 5 after 4 hrs. The subsequent drop-off is not as rapid. The gamma-ray source (in 
photons/s) as a function of time and cell number is shown on Table 3. It is seen that the source is approximately $3.5 \times 10^{10}$ photons/s immediately after shutdown, but then drops off by approximately an order of magnitude following $4 \mathrm{hrs}$. As with the activity, the variation following $4 \mathrm{hrs}$ is much slower, and even following 30 days there is a significant source. Immediately after shutdown the activity is dominated by isotopes of copper, nickel, iron, manganese, vanadium, cobalt, oxygen, carbon, and aluminum. The short lived isotopes decay within the $4 \mathrm{hr}$ period and the activity is then dominated by ${ }^{63} \mathrm{Ni},{ }^{60} \mathrm{Co},{ }^{58} \mathrm{Co},{ }^{57} \mathrm{Co},{ }^{56} \mathrm{Co},{ }^{55} \mathrm{Fe}$, ${ }^{54} \mathrm{Mn},{ }^{14} \mathrm{C}$, and ${ }^{10} \mathrm{Be}$. The production of tritium in the cooling water is extremely small (approximately $10^{-15}$ Curies per cell), and a more accurate value will have to be determined at a later date.

\section{Tunnel Atmosphere}

An estimate of the tunnel atmosphere was made at several locations along the tunnel shown in Fig 7. Nitrogen, oxygen, hydrogen, and argon were included in the description of the atmosphere. Immediately following shutdown the activity is dominated by ${ }^{13} \mathrm{~N},{ }^{37} \mathrm{Ar},{ }^{39} \mathrm{Cl}$, and ${ }^{16} \mathrm{~N}$. Following $4 \mathrm{hrs}$ the activity is dominated by ${ }^{14} \mathrm{C}$, and in selected cells ${ }^{10} \mathrm{Be} .{ }^{3} \mathrm{H}$ is generated in all cases, but in extremely small quantities. The gamma-ray source is dominated by the presence of ${ }^{14} \mathrm{C}$. A detailed accounting of the long lived isotopes indicates that the inventories are:

$\begin{array}{lr}\text { Isotope } & \text { Activity (Curies) } \\ \text { Tritium } & 1.0 \times 10^{-10} \\ \text { Beryllium-7 } & 1.4 \times 10^{-9} \\ \text { Carbon-7 } & 1.1 \times 10^{-3}\end{array}$

In a real atmosphere the air would likely be circulated and vented following an appropriate holdup to ensure that the short lived isotopes have decayed. In this manner the build-up of activity will be limited by the time the air is exposed to the implied radiation environment. In the above estimates the exposure time was 180 days.

\section{Tunnel cooling water}

The location of the tunnel cooling water line has not been fixed yet. Thus two locations were investigated for this estimate. In the first case it is assumed that the cooling pipe runs along the inside tunnel wall, at essentially floor level, and in the second case it is assumed the cooling pipe runs along the outside tunnel wall and is suspended approximately $1.5 \mathrm{~m}$ below the ceiling. These arrangements are shown in Fig. 6. Several cells on either side of the scraper/collimator were used to estimate the activity. The results shown on Table 2 indicate that the activity immediately following shutdown is dominated by ${ }^{15} \mathrm{O},{ }^{16} \mathrm{~N}$, and ${ }^{7} \mathrm{Be}$ in selected cells. Following 4 hrs the activity is dominated by ${ }^{14} \mathrm{C}$ and ${ }^{7} \mathrm{Be}$ in selected cells. Of the two locations considered for the cooling water line, the one along the outside wall below the ceiling has a total activity significantly lower than that of a line located along the inside wall just above the floor. The final location of the cooling line will have to satisfy additional constraints such as ease of connecting to machine components, ease of shielding if necessary, and ease of maintenance. The total 
inventory of relatively long lived isotopes for the two locations are given below:

$\begin{array}{lcc}\begin{array}{l}\text { Nuclide } \\ \text { Along inside wall } \\ \text { (Curies) }\end{array} & \begin{array}{c}\text { Along outside wall } \\ \text { (Curies) }\end{array} \\ \text { Tritium } & 4.2 \times 10^{-10} & 4.1 \times 10^{-11} \\ \text { Beryllium-7 } & 2.4 \times 10^{-3} & 1.5 \times 10^{-3} \\ \text { Beryllium-10 } & 3.6 \times 10^{-10} & \sim \\ \text { Carbon-14 } & 4.0 \times 10^{-7} & 4.0 \times 10^{-7}\end{array}$

The above estimates will have to be updated to include additional losses along the collimation straight, the total inventory of the cooling water loop, and the flow velocity (which determines the duration of the water will spend in a potentially high loss section of the ring).

\section{Conclusions}

The following conclusions can be drawn from this study:

1) The results reported in this study are a strong function of the assumptions regarding loss, average power and full power operating time,

2) In this study it was assumed that the loss is 0.001 of the beam on the face of each of the collimators, the accelerator operated at an average power of $2 \mathrm{MW}$ in an un-interrupted fashion for 180 days. The effect of any variation from these assumptions can be obtained by scaling (within limits), and

3) Once a firmed up design is established these estimates can be repeated for realistic loss patterns, operating profiles, and power levels.

\section{References}

1) MCNPX Users Manual - Version 2.1.5, L.S. Waters, ed., Los Alamos National Laboratory, Los Alamos, NM, TPO-E83-G-UG-X-00001 (1999)

2) R.E. Prael and H. Lichtenstein, "User Guide to LCS: The LAHET Code System", Los Alamos National Laboratory, Los Alamos, NM, LA-UR-89-3014 (1989).

3) MCNP-A General Monte Carlo N-Particle Transport Code Version 4A, J.F. Breismeister, ed., Los Alamos National Laboratory, Los Alamos, NM, LA-12625-M (1993).

4) A.G. Croff, "ORIGEN2 - A Revised and Updated Version of the Oak Ridge Isotope Generation and Depletion Code", Oak Ridge National Laboratory, Oak Ridge, TN, ORNL-5621 (1980). 
TABLE 1 -

ACTIVATION OF COMPONENTS IN COLLIMATION STRAIGHT OF RING

Cell number neutron col 1 photon col 1 Total Dose col 1 neutron col 2 photon col 2 Total dose col2 neutron col 3 photon col 3 Total Dose col 3 Total all collimators

\begin{tabular}{|c|c|c|c|c|c|c|c|c|c|c|}
\hline 2048 & $3.49 \mathrm{E}+02$ & $1.46 \mathrm{E}+03$ & 1809 & $2.63 \mathrm{E}+00$ & $1.02 \mathrm{E}+03$ & 1027.2303 & $0.00 \mathrm{E}+00$ & $0.00 \mathrm{E}+00$ & 0 & 2836.230 \\
\hline 2049 & $4.62 \mathrm{E}+02$ & $3.18 \mathrm{E}+03$ & 3642 & $2.80 \mathrm{E}-01$ & $4.70 \mathrm{E}+00$ & 4.975869 & $0.00 \mathrm{E}+00$ & $0.00 \mathrm{E}+00$ & 0 & 3646.975869 \\
\hline 2050 & $1.77 \mathrm{E}+02$ & $2.11 \mathrm{E}+03$ & 2287 & $6.98 \mathrm{E}+00$ & $5.85 \mathrm{E}+02$ & 591.57568 & $0.00 \mathrm{E}+00$ & $0.00 \mathrm{E}+00$ & 0 & 2878.57568 \\
\hline 2051 & $3.70 \mathrm{E}+02$ & $1.17 \mathrm{E}+03$ & 1540 & $6.44 \mathrm{E}+00$ & $2.85 \mathrm{E}+03$ & 2853.90198 & $0.00 \mathrm{E}+00$ & $2.27 \mathrm{E}+01$ & 22.6737 & 4416.575 \\
\hline 2053 & $1.46 \mathrm{E}+03$ & $3.87 \mathrm{E}+04$ & 40160 & $2.54 \mathrm{E}+02$ & $5.14 \mathrm{E}+03$ & 5393.688 & 2.15E-01 & $6.11 \mathrm{E}+00$ & 6.327352 & 45560.0153 \\
\hline 2054 & $1.99 \mathrm{E}+03$ & $5.02 E+04$ & 52190 & $4.06 \mathrm{E}+02$ & $1.07 \mathrm{E}+04$ & 11119.309 & $9.92 \mathrm{E}-01$ & $2.22 \mathrm{E}+02$ & 223.326246 & 63532.63525 \\
\hline 2055 & $1.68 \mathrm{E}+03$ & $4.25 \mathrm{E}+04$ & 44180 & $3.18 \mathrm{E}+02$ & $7.78 \mathrm{E}+03$ & 8095.958 & 3.53E-01 & $0.00 \mathrm{E}+00$ & 0.353324 & 52276.311 \\
\hline 2056 & $2.60 \mathrm{E}+03$ & $4.09 \mathrm{E}+04$ & 43500 & $3.27 \mathrm{E}+02$ & $9.44 \mathrm{E}+03$ & 9771.213 & $5.67 \mathrm{E}+00$ & $5.53 \mathrm{E}+02$ & 558.55164 & 53829.764 \\
\hline$\overline{1601}$ & $4.16 \mathrm{E}+05$ & $1.57 \mathrm{E}+06$ & $19 \overline{86000}$ & $1.10 \mathrm{E}+03$ & $3.75 \mathrm{E}+04$ & 38606.2 & $2.53 \mathrm{E}+00$ & $3.07 \mathrm{E}+02$ & 309.11904 & 2024915.3 \\
\hline 1607 & $4.74 \mathrm{E}+05$ & $1.78 \mathrm{E}+06$ & 2254000 & $1.12 \mathrm{E}+03$ & $3.23 \mathrm{E}+04$ & 33378.9 & $3.16 \mathrm{E}-01$ & $4.64 \mathrm{E}+02$ & 464.092427 & 2287842.9 \\
\hline 1609 & $7.12 \mathrm{E}+05$ & $2.77 \mathrm{E}+06$ & 3482000 & $1.56 \mathrm{E}+03$ & $7.24 \mathrm{E}+04$ & 73964.62 & $0.00 \mathrm{E}+00$ & $0.00 \mathrm{E}+00$ & 0 & 3555964. \\
\hline 1619 & $8.56 \mathrm{E}+05$ & $3.22 \mathrm{E}+06$ & 4076000 & $1.43 \mathrm{E}+03$ & $3.05 \mathrm{E}+04$ & 31956.02 & $1.94 \mathrm{E}-01$ & $4.35 \mathrm{E}+02$ & 435.327974 & 4108391.3 \\
\hline 1625 & $8.61 \mathrm{E}+05$ & $3.20 E+06$ & 4061000 & $1.34 \mathrm{E}+03$ & $3.31 \mathrm{E}+04$ & 34433.64 & $2.21 \mathrm{E}+01$ & $4.65 \mathrm{E}+02$ & 487.0757 & 4095920.7 \\
\hline 1626 & $4.85 E+05$ & $1.76 \mathrm{E}+06$ & 2245000 & $5.40 \mathrm{E}+02$ & $3.25 \mathrm{E}+04$ & 33048.529 & $4.01 \mathrm{E}+00$ & $4.42 \mathrm{E}+03$ & 4420.89186 & 2282469.4 \\
\hline 1628 & $7.15 \mathrm{E}+05$ & $2.73 E+06$ & 3445000 & $8.93 E+02$ & $2.29 \mathrm{E}+04$ & 23760.158 & $1.32 \mathrm{E}+01$ & $0.00 \mathrm{E}+00$ & 13.2431 & 3468773.4 \\
\hline 1629 & $4.18 \mathrm{E}+05$ & $1.51 \mathrm{E}+06$ & 1928000 & $1.02 E+03$ & $3.41 \mathrm{E}+04$ & 35097.16 & $1.16 \mathrm{E}+01$ & $6.98 \mathrm{E}+02$ & 709.1689 & 1963806.3 \\
\hline 1630 & $4.21 \mathrm{E}+05$ & $1.58 \mathrm{E}+06$ & 2001000 & $1.12 \mathrm{E}+03$ & $3.68 \mathrm{E}+04$ & 37949.11 & $5.54 \mathrm{E}+00$ & $5.98 \mathrm{E}+02$ & 603.62382 & 2039552.7 \\
\hline 1631 & $4.56 \mathrm{E}+05$ & $1.64 \mathrm{E}+06$ & 2096000 & $8.23 \mathrm{E}+02$ & $2.02 \mathrm{E}+04$ & 21049.854 & $1.12 \mathrm{E}+01$ & $0.00 \mathrm{E}+00$ & 11.2128 & 2117061.0 \\
\hline 1633 & $6.99 \mathrm{E}+05$ & $2.75 \mathrm{E}+06$ & 3449000 & $1.09 \mathrm{E}+03$ & $4.98 \mathrm{E}+04$ & 50902.85 & $1.59 \mathrm{E}-02$ & $0.00 \mathrm{E}+00$ & 0.0158831 & 3499902.8 \\
\hline 1634 & $8.57 \mathrm{E}+05$ & $3.22 \mathrm{E}+06$ & 4077000 & $1.11 \mathrm{E}+03$ & $2.72 \mathrm{E}+04$ & 28346.76 & $3.15 \mathrm{E}+01$ & $1.19 \mathrm{E}+03$ & 1217.1486 & 4106563.9 \\
\hline 1640 & $8.65 E+05$ & $3.19 E+06$ & 4055000 & $9.42 \mathrm{E}+02$ & $3.25 \mathrm{E}+04$ & 33394.829 & $2.09 \mathrm{E}+00$ & $7.21 \mathrm{E}+02$ & 722.88819 & 4089117.7 \\
\hline 1650 & $5.19 \mathrm{E}+05$ & $1.79 \mathrm{E}+06$ & 2309000 & 7.17E+02 & $2.91 \mathrm{E}+04$ & 29804.302 & $2.52 \mathrm{E}+01$ & $6.12 \mathrm{E}+03$ & 6149.2815 & 2344953.5 \\
\hline 1652 & $6.98 \mathrm{E}+05$ & $2.66 \mathrm{E}+06$ & 3358000 & $1.39 \mathrm{E}+03$ & $6.03 E+04$ & 61688.48 & 2.42E-01 & $0.00 \mathrm{E}+00$ & 0.241636 & 3419688.7 \\
\hline 1658 & $4.22 \mathrm{E}+05$ & $1.50 \mathrm{E}+06$ & 1922000 & $9.32 \mathrm{E}+02$ & $3.59 \mathrm{E}+04$ & 36877.72 & $3.56 \mathrm{E}+00$ & $3.02 \mathrm{E}+02$ & $\underline{305.83549}$ & 1959183.5 \\
\hline$\overline{1048}$ & $\overline{1.15 E+06}$ & $\overline{2.81 \mathrm{E}+06}$ & 3960000 & $\overline{1.76 \mathrm{E}+03}$ & $\overline{4.10 E+04}$ & 42774.71 & $\overline{1.41 \mathrm{E}-01}$ & $\overline{2.54 \mathrm{E}+02}$ & 253.937 & 4003028.6 \\
\hline 1049 & $1.14 \mathrm{E}+06$ & $2.77 \mathrm{E}+06$ & 3910000 & $1.34 \mathrm{E}+03$ & $3.15 \mathrm{E}+04$ & 32852.35 & $2.20 \mathrm{E}+01$ & $3.09 \mathrm{E}+03$ & 3113.9746 & 3945966.3 \\
\hline 1050 & $1.18 \mathrm{E}+06$ & $2.86 \mathrm{E}+06$ & 4040000 & $1.92 \mathrm{E}+03$ & $3.35 \mathrm{E}+04$ & 35460.91 & $1.42 \mathrm{E}+00$ & $1.24 \mathrm{E}+03$ & 1242.71797 & 4076703.6 \\
\hline 1051 & $1.15 \mathrm{E}+06$ & $2.73 E+06$ & 3880000 & $2.06 \mathrm{E}+03$ & $3.17 \mathrm{E}+04$ & 33716.94 & $1.14 \mathrm{E}+00$ & $4.64 \mathrm{E}+02$ & 465.06196 & 3914182.0 \\
\hline 1053 & $1.22 \mathrm{E}+06$ & $3.17 \mathrm{E}+06$ & 4390000 & $7.79 \mathrm{E}+03$ & $7.66 \mathrm{E}+04$ & 84419.93 & $2.17 \mathrm{E}+00$ & $9.98 \mathrm{E}+02$ & 1000.63655 & 4475420.5 \\
\hline 1054 & $1.20 \mathrm{E}+06$ & $3.08 \mathrm{E}+06$ & 4280000 & $7.67 \mathrm{E}+03$ & $6.50 \mathrm{E}+04$ & 72695.04 & $8.31 E+00$ & $1.44 \mathrm{E}+03$ & 1452.60606 & 4354147.6 \\
\hline 1055 & $1.21 \mathrm{E}+06$ & $3.15 \mathrm{E}+06$ & 4360000 & $7.59 \mathrm{E}+03$ & $8.20 E+04$ & 89616.45 & $1.96 \mathrm{E}+01$ & $7.34 \mathrm{E}+00$ & 26.93026 & 4449643. \\
\hline 1056 & $1.20 \mathrm{E}+06$ & $3.03 E+06$ & 4230000 & $8.01 \mathrm{E}+03$ & $7.58 \mathrm{E}+04$ & 83827.4 & $1.06 \mathrm{E}+01$ & $9.44 \mathrm{E}+02$ & 954.8187 & 4314782.2 \\
\hline$\overline{1248}$ & $\overline{1.45 E+06}$ & $\overline{3.68 \mathrm{E}+06}$ & $\overline{5130000}$ & $\overline{7.13 E+03}$ & $\overline{7.78 \mathrm{E}+04}$ & $8 \overline{8957.51}$ & $\overline{5.75 \mathrm{E}+00}$ & $\overline{7.85 \mathrm{E}+02}$ & 790.726 & 5215748.2 \\
\hline 1249 & $1.44 \mathrm{E}+06$ & $3.57 \mathrm{E}+06$ & 5010000 & $5.85 \mathrm{E}+03$ & $7.70 \mathrm{E}+04$ & 82852.04 & $1.93 \mathrm{E}+00$ & $4.58 \mathrm{E}+02$ & 460.27334 & 5093312.3 \\
\hline 1250 & $1.47 \mathrm{E}+06$ & $3.64 \mathrm{E}+06$ & 5110000 & $6.23 \mathrm{E}+03$ & $7.11 \mathrm{E}+04$ & 77338.24 & $4.47 \mathrm{E}+00$ & $4.74 \mathrm{E}+02$ & 478.31439 & 5187816.5 \\
\hline 1251 & $1.46 \mathrm{E}+06$ & $3.51 \mathrm{E}+06$ & 4970000 & $5.48 \mathrm{E}+03$ & $5.34 \mathrm{E}+04$ & 58927.47 & $1.11 \mathrm{E}+00$ & $3.86 \mathrm{E}+02$ & 386.9838 & 5029314.4 \\
\hline 1253 & $1.28 \mathrm{E}+06$ & $3.18 \mathrm{E}+06$ & 4460000 & $8.19 E+04$ & $2.67 \mathrm{E}+05$ & 348772 & $4.51 \mathrm{E}+00$ & $6.22 \mathrm{E}+02$ & 626.64129 & 4809398.6 \\
\hline 1254 & $1.24 \mathrm{E}+06$ & $3.04 \mathrm{E}+06$ & 4280000 & $7.95 \mathrm{E}+04$ & $2.67 \mathrm{E}+05$ & 346625.2 & $5.46 \mathrm{E}+01$ & $9.96 \mathrm{E}+02$ & 1050.56 & 4627675. \\
\hline 1255 & $1.27 \mathrm{E}+06$ & $3.17 \mathrm{E}+06$ & 4440000 & $7.66 \mathrm{E}+04$ & $2.78 \mathrm{E}+05$ & 354244.3 & 4.45E-01 & 1.37E+02 & 137.892741 & 4794382.1 \\
\hline 1256 & $1.27 \mathrm{E}+06$ & $3.13 E+06$ & 4400000 & $7.55 \mathrm{E}+04$ & $2.72 \mathrm{E}+05$ & 347462.4 & $2.38 \mathrm{E}+00$ & $1.35 \mathrm{E}+02$ & 136.97119 & 4747599.3 \\
\hline$\overline{4048}$ & $\overline{4.65 E+03}$ & $3.35 \mathrm{E}+04$ & 38150 & $\overline{5.10 \mathrm{E}+04}$ & $\overline{1.55 \mathrm{E}+05}$ & 206345.3 & $\overline{2.00 E+02}$ & $\overline{1.32 \mathrm{E}+04}$ & $\overline{13366.548}$ & 257861.8 \\
\hline 4049 & $3.49 \mathrm{E}+03$ & $2.86 \mathrm{E}+04$ & 32090 & $5.01 \mathrm{E}+04$ & $1.44 \mathrm{E}+05$ & 194126.5 & $3.91 \mathrm{E}+02$ & $9.28 \mathrm{E}+03$ & 9668.93 & 235885 . \\
\hline 4050 & $3.86 \mathrm{E}+03$ & $2.54 \mathrm{E}+04$ & 29260 & $4.76 \mathrm{E}+04$ & $1.37 \mathrm{E}+05$ & 184251.2 & $1.82 \mathrm{E}+02$ & $1.22 \mathrm{E}+04$ & 12386.122 & 225897.3 \\
\hline 4051 & $3.59 \mathrm{E}+03$ & $3.06 \mathrm{E}+04$ & 34190 & $5.11 \mathrm{E}+04$ & $1.48 \mathrm{E}+05$ & 198926.4 & $1.41 \mathrm{E}+02$ & $8.71 \mathrm{E}+03$ & 8853.035 & 241969.4 \\
\hline 4053 & $5.54 \mathrm{E}+03$ & $2.67 \mathrm{E}+04$ & 32240 & $2.96 \mathrm{E}+04$ & $9.66 \mathrm{E}+04$ & 126188.1 & $3.64 \mathrm{E}+02$ & $1.37 \mathrm{E}+04$ & 14054.113 & 172482.2 \\
\hline 4054 & $6.37 \mathrm{E}+03$ & $2.40 \mathrm{E}+04$ & 30370 & $2.78 \mathrm{E}+04$ & $9.22 \mathrm{E}+04$ & 120070.7 & $6.23 \mathrm{E}+02$ & $2.04 \mathrm{E}+04$ & 21030.674 & 171471.3 \\
\hline 4055 & $5.37 \mathrm{E}+03$ & $2.40 E+04$ & 29370 & $3.05 \mathrm{E}+04$ & $1.04 \mathrm{E}+05$ & 134200.2 & $4.78 \mathrm{E}+02$ & $2.54 \mathrm{E}+04$ & 25858.709 & 189428.9 \\
\hline$\underline{4056}$ & $\underline{5.36 \mathrm{E}+03}$ & $2.52 \mathrm{E}+04$ & 30560 & $2.53 \mathrm{E}+04$ & $9.22 \mathrm{E}+04$ & 117526.3 & $3.20 \mathrm{E}+02$ & $1.67 \mathrm{E}+04$ & 16980.015 & 165066.3 \\
\hline$\overline{4248}$ & $6.65 \mathrm{E}+03$ & $2.65 \mathrm{E}+04$ & 33150 & $3.74 \mathrm{E}+04$ & $1.10 \mathrm{E}+05$ & $\overline{147082.4}$ & $2.99 \mathrm{E}+02$ & $\overline{1.69 \mathrm{E}+04}$ & 17149.262 & 197381.6 \\
\hline 4249 & $8.19 E+03$ & $3.72 E+04$ & 45390 & $3.44 \mathrm{E}+04$ & $1.09 \mathrm{E}+05$ & 143012.9 & $6.05 \mathrm{E}+02$ & $2.20 \mathrm{E}+04$ & 22579.838 & 210982.7 \\
\hline 425 & $8.00 \mathrm{E}+03$ & $3.32 E+04$ & 41200 & $3.42 \mathrm{E}+04$ & $9.00 \mathrm{E}+04$ & 124137.5 & $5.99 \mathrm{E}+02$ & $1.82 \mathrm{E}+04$ & 18827.512 & 184165.0 \\
\hline 4251 & $8.99 \mathrm{E}+03$ & $3.64 \mathrm{E}+04$ & 45390 & $3.24 \mathrm{E}+04$ & $1.08 \mathrm{E}+05$ & 140349 & $2.72 \mathrm{E}+02$ & $1.51 \mathrm{E}+04$ & 15415.386 & 201154.3 \\
\hline
\end{tabular}

Remark

First Quadru-pole

Corrector Magnet

Cells

First Quadru-pole

First Doublet

Second Quadru-pole

First Doublet

First Quadru-pole

of

Second Doublet 


\begin{tabular}{|c|c|c|c|c|c|c|c|c|c|c|c|}
\hline Cell number & neutron col & & $a r$ & neutr & & Total d & & & & Total & Remark \\
\hline 4253 & $9.88 \mathrm{E}+03$ & $2.62 \mathrm{E}+04$ & 36080 & $2.14 \mathrm{E}+04$ & $6.97 \mathrm{E}+04$ & 91107.5 & $2.48 \mathrm{E}+03$ & $3.70 \mathrm{E}+04$ & 39470.31 & 166657.81 & of \\
\hline 4254 & $9.76 \mathrm{E}+03$ & $3.36 \mathrm{E}+04$ & 43360 & $2.34 \mathrm{E}+04$ & $5.61 \mathrm{E}+04$ & 79475.1 & $2.49 E+03$ & $3.69 \mathrm{E}+04$ & 39343.75 & 162178.85 & Second Doublet \\
\hline 4255 & $1.11 \mathrm{E}+04$ & $2.52 \mathrm{E}+04$ & 36300 & $2.18 \mathrm{E}+04$ & $6.24 \mathrm{E}+04$ & 84249.5 & $2.96 \mathrm{E}+03$ & $3.62 \mathrm{E}+04$ & 39140 & 159689.5 & \\
\hline 4256 & $7.93 \mathrm{E}+03$ & $2.06 \mathrm{E}+04$ & $\underline{28530}$ & $1.91 \mathrm{E}+04$ & $6.68 \mathrm{E}+04$ & 85857.9 & $2.22 \mathrm{E}+03$ & $2.99 \mathrm{E}+04$ & $\underline{32116.02}$ & 146503.92 & \\
\hline$\overline{1148}$ & $7.83 E+02$ & $3.46 \mathrm{E}+03$ & 4243 & $\overline{5.81 \mathrm{E}+02}$ & $2.79 \mathrm{E}+03$ & $3 \overline{371.898}$ & $1.84 \mathrm{E}+05$ & $4.42 \mathrm{E}+05$ & 625894 & $6 \overline{33508.898}$ & \\
\hline 1149 & $8.89 \mathrm{E}+02$ & $2.15 E+03$ & 3039 & $4.56 \mathrm{E}+02$ & $3.06 \mathrm{E}+03$ & 3512.159 & $1.68 \mathrm{E}+05$ & $4.12 \mathrm{E}+05$ & 579220 & 585771.159 & \\
\hline 1150 & $6.65 \mathrm{E}+02$ & $4.11 \mathrm{E}+03$ & 4775 & $6.15 \mathrm{E}+02$ & $3.54 \mathrm{E}+03$ & 4152.101 & $1.70 \mathrm{E}+05$ & $4.07 \mathrm{E}+05$ & 577594 & 586521.101 & \\
\hline 1151 & $9.12 \mathrm{E}+02$ & $1.44 \mathrm{E}+03$ & 2352 & $7.94 \mathrm{E}+02$ & $5.67 \mathrm{E}+03$ & 6468.155 & $1.65 \mathrm{E}+05$ & $4.11 \mathrm{E}+05$ & 575199 & 584019.155 & Last Quadru-pole \\
\hline 1153 & $1.68 \mathrm{E}+02$ & $2.69 \mathrm{E}+01$ & 194.9 & $2.17 \mathrm{E}+02$ & $4.68 \mathrm{E}+02$ & 684.889 & $1.62 \mathrm{E}+05$ & $3.54 \mathrm{E}+05$ & 516000 & 516879.789 & \\
\hline 1154 & $5.26 \mathrm{E}+02$ & $1.44 \mathrm{E}+03$ & 1966 & $3.32 \mathrm{E}+02$ & $1.65 \mathrm{E}+03$ & 1981.272 & $1.66 \mathrm{E}+05$ & $3.49 \mathrm{E}+05$ & 514855 & 518802.272 & \\
\hline 1155 & $5.36 \mathrm{E}+02$ & $1.71 \mathrm{E}+03$ & 2246 & $1.27 \mathrm{E}+02$ & $3.10 \mathrm{E}+02$ & 437.632 & $1.63 E+05$ & $3.63 \mathrm{E}+05$ & 525905 & 528588.632 & \\
\hline 1156 & $4.55 \mathrm{E}+02$ & $1.37 \mathrm{E}+03$ & 1825 & $1.18 \mathrm{E}+03$ & $2.34 \mathrm{E}+03$ & 3520.55 & $1.63 E+05$ & $3.45 \mathrm{E}+05$ & 508823 & $\underline{514168.55}$ & \\
\hline 361 & $5.95 E+04$ & $\overline{4.48 \mathrm{E}+04}$ & $10 \overline{4300}$ & $\overline{1.16 \mathrm{E}+04}$ & $\overline{9.02 E+03}$ & $2 \overline{0576.57}$ & $5.65 \mathrm{E}+02$ & $4.45 \mathrm{E}+02$ & $10 \overline{009.804}$ & $1 \overline{25886.374}$ & \\
\hline 371 & $1.96 \mathrm{E}+05$ & $1.46 \mathrm{E}+05$ & 342000 & $2.85 \mathrm{E}+04$ & $2.19 \mathrm{E}+04$ & 50358 & $1.08 \mathrm{E}+03$ & $8.31 E+02$ & 1911.25 & 394269.25 & \\
\hline 381 & $7.01 \mathrm{E}+05$ & $4.54 \mathrm{E}+05$ & 1155000 & $7.51 \mathrm{E}+04$ & $5.01 \mathrm{E}+04$ & 125212 & $2.16 \mathrm{E}+03$ & $1.36 \mathrm{E}+03$ & 3516.12 & 1283728.12 & Cable along inside \\
\hline 391 & $8.27 \mathrm{E}+05$ & $5.06 \mathrm{E}+05$ & 1333000 & $1.10 \mathrm{E}+05$ & $7.46 \mathrm{E}+04$ & 184906 & $2.34 \mathrm{E}+03$ & $2.06 \mathrm{E}+03$ & 4393.91 & 1522299.91 & wall - first level above \\
\hline 401 & $3.34 \mathrm{E}+05$ & $2.26 \mathrm{E}+05$ & 560000 & $1.64 \mathrm{E}+05$ & $1.05 E+05$ & 268165 & $3.31 E+03$ & $2.93 \mathrm{E}+03$ & 6243.59 & 834408.59 & Collimator \\
\hline 411 & $1.09 \mathrm{E}+05$ & $8.43 \mathrm{E}+04$ & 193300 & $1.77 \mathrm{E}+05$ & $1.20 \mathrm{E}+05$ & 296607 & $8.89 \mathrm{E}+03$ & $6.97 \mathrm{E}+03$ & 15851.45 & 505758.45 & \\
\hline 421 & $6.70 \mathrm{E}+04$ & $4.85 \mathrm{E}+04$ & 115500 & $1.66 \mathrm{E}+05$ & $1.03 E+05$ & 268586 & $1.50 \mathrm{E}+04$ & $9.99 \mathrm{E}+03$ & 25008.15 & 409094.15 & \\
\hline 431 & $5.10 E+04$ & $3.85 \mathrm{E}+04$ & 89500 & $1.30 \mathrm{E}+05$ & $8.27 \mathrm{E}+04$ & 213055.1 & $1.93 E+04$ & $1.37 \mathrm{E}+04$ & 32990.2 & 335545.3 & \\
\hline 441 & $3.46 \mathrm{E}+04$ & $2.55 E+04$ & 60100 & $9.93 E+04$ & $6.15 E+04$ & 160866.2 & $2.83 E+04$ & $2.05 \mathrm{E}+04$ & 48768.2 & 269734.4 & \\
\hline 445 & $2.44 \mathrm{E}+04$ & $1.65 \mathrm{E}+04$ & 40900 & $5.93 E+04$ & $3.89 \mathrm{E}+04$ & 98186.9 & $6.61 \mathrm{E}+04$ & $4.43 \mathrm{E}+04$ & 110399.5 & 249486.4 & \\
\hline 449 & $1.09 \mathrm{E}+04$ & $7.33 \mathrm{E}+03$ & 18230 & $2.51 \mathrm{E}+04$ & $1.60 \mathrm{E}+04$ & 41010.7 & $1.25 \mathrm{E}+05$ & $7.54 \mathrm{E}+04$ & 200365.7 & 259606.4 & \\
\hline 453 & $3.75 E+03$ & $\underline{3.03 E+03}$ & $\underline{6780}$ & $1.22 \mathrm{E}+04$ & $6.57 \mathrm{E}+03$ & $\underline{18724.28}$ & $6.56 \mathrm{E}+04$ & $4.09 \mathrm{E}+04$ & 106469.1 & 131973.38 & \\
\hline 32 & $\overline{2.72 E+04}$ & $\overline{1.98 E+04}$ & $4 \overline{7000}$ & $\overline{5.19 \mathrm{E}+03}$ & $3.83 E+03$ & 9019.06 & $3.06 \mathrm{E}+02$ & $2.28 \mathrm{E}+02$ & 534.674 & $\overline{56553.734}$ & \\
\hline 34 & $2.46 \mathrm{E}+05$ & $1.72 \mathrm{E}+05$ & 418000 & $2.46 \mathrm{E}+04$ & $1.82 \mathrm{E}+04$ & 42731.6 & $9.80 \mathrm{E}+02$ & $7.13 \mathrm{E}+02$ & 1692.421 & 462424.021 & Tunnel Air \\
\hline 3003 & $2.87 \mathrm{E}+05$ & $1.93 \mathrm{E}+05$ & 480000 & $3.54 \mathrm{E}+04$ & $2.55 \mathrm{E}+04$ & 60909.8 & $1.23 E+03$ & $9.02 \mathrm{E}+02$ & 2127.242 & 543037.042 & \\
\hline 4065 & $1.44 \mathrm{E}+04$ & $1.01 \mathrm{E}+04$ & 24500 & $4.28 \mathrm{E}+04$ & $2.76 \mathrm{E}+04$ & 70392.8 & $1.04 \mathrm{E}+04$ & $7.05 \mathrm{E}+03$ & 17491.66 & 112384.46 & \\
\hline 1167 & $2.25 \mathrm{E}+03$ & $1.76 \mathrm{E}+03$ & 4010 & $6.26 \mathrm{E}+03$ & $4.12 \mathrm{E}+03$ & 10382.17 & $2.32 \mathrm{E}+04$ & $1.54 \mathrm{E}+04$ & $\underline{38579.1}$ & $\underline{52971.27}$ & \\
\hline 5041 & $2.04 \mathrm{E}-03$ & $1.48 \mathrm{E}-02$ & $0.0 \overline{1684}$ & $0.00 \mathrm{E}+00$ & $0.00 \mathrm{E}+00$ & 0 & $0.00 \mathrm{E}+00$ & $0.00 \mathrm{E}+00$ & 0 & 0.01684 & \\
\hline 5046 & $5.72 \mathrm{E}-02$ & 1.13E-01 & 0.1702 & $0.00 \mathrm{E}+00$ & $0.00 E+00$ & 0 & $0.00 \mathrm{E}+00$ & $0.00 \mathrm{E}+00$ & 0 & 0.1702 & \\
\hline 5511 & $5.36 \mathrm{E}-01$ & $8.66 \mathrm{E}-01$ & 1.402 & $3.64 \mathrm{E}-02$ & 4.19E-02 & 0.0783127 & $0.00 \mathrm{E}+00$ & $0.00 \mathrm{E}+00$ & 0 & 1.4803127 & \\
\hline 6041 & $1.40 \mathrm{E}+00$ & $2.37 E+00$ & 3.77 & $1.30 \mathrm{E}-01$ & $1.90 \mathrm{E}-01$ & 0.319948 & $0.00 \mathrm{E}+00$ & $0.00 \mathrm{E}+00$ & 0 & 4.089948 & Outside of Earth berm \\
\hline 6046 & $1.45 \mathrm{E}+00$ & $2.16 \mathrm{E}+00$ & 3.61 & 2.10E-01 & 3.07E-01 & 0.517361 & $0.00 \mathrm{E}+00$ & $0.00 \mathrm{E}+00$ & 0 & 4.127361 & inside of Ring \\
\hline 6511 & $2.89 \mathrm{E}-01$ & $5.89 \mathrm{E}-01$ & 0.878 & 2.82E-01 & $4.85 \mathrm{E}-01$ & 0.767241 & $0.00 \mathrm{E}+00$ & $0.00 \mathrm{E}+00$ & 0 & 1.645241 & \\
\hline 7041 & $5.27 \mathrm{E}-02$ & $6.09 \mathrm{E}-02$ & 0.1136 & 7.07E-01 & $1.26 \mathrm{E}+00$ & 1.970312 & $0.00 \mathrm{E}+00$ & $0.00 \mathrm{E}+00$ & 0 & 2.083912 & \\
\hline 7046 & $5.31 \mathrm{E}-02$ & 7.91E-02 & 0.1322 & 7.81E-01 & $1.22 \mathrm{E}+00$ & 2.00173 & $0.00 \mathrm{E}+00$ & $0.00 \mathrm{E}+00$ & 0 & 2.13393 & \\
\hline 7511 & $1.73 \mathrm{E}-02$ & 4.76E-02 & 0.0649 & $5.54 \mathrm{E}-01$ & $7.76 \mathrm{E}-01$ & 1.329756 & $9.72 \mathrm{E}-07$ & $0.00 \mathrm{E}+00$ & $9.72171 \mathrm{E}-07$ & 1.394656972 & \\
\hline 8041 & $2.46 \mathrm{E}-02$ & $2.57 \mathrm{E}-02$ & 0.0503 & 2.92E-01 & 4.57E-01 & 0.749336 & $2.78 \mathrm{E}-03$ & $3.14 \mathrm{E}-03$ & 0.00591681 & 0.80555281 & \\
\hline 8046 & $2.85 \mathrm{E}-02$ & $4.46 \mathrm{E}-02$ & 0.0731 & $2.08 \mathrm{E}-01$ & $2.66 \mathrm{E}-01$ & 0.473647 & $1.42 \mathrm{E}-01$ & 2.26E-01 & 0.367684 & 0.914431 & \\
\hline 8511 & $1.47 \mathrm{E}-02$ & $3.18 \mathrm{E}-02$ & $\underline{0.0465}$ & $7.15 \mathrm{E}-02$ & $1.49 \mathrm{E}-01$ & $\underline{0.2210156}$ & $1.69 \mathrm{E}-01$ & 2.63E-01 & 0.431554 & $\underline{0.6990696}$ & \\
\hline 5042 & $1.60 \mathrm{E}-02$ & $3.70 \mathrm{E}-02$ & 0.053 & $0.00 \mathrm{E}+00$ & $0.00 \mathrm{E}+00$ & 0 & $0.00 \mathrm{E}+00$ & $0.00 \mathrm{E}+00$ & 0 & 0.053 & \\
\hline 5047 & $6.75 \mathrm{E}-02$ & $9.78 \mathrm{E}-02$ & 0.1653 & $0.00 \mathrm{E}+00$ & $2.09 \mathrm{E}-03$ & 0.00209056 & $0.00 \mathrm{E}+00$ & $0.00 \mathrm{E}+00$ & 0 & 0.16739056 & \\
\hline 5512 & $1.95 \mathrm{E}-01$ & $2.59 \mathrm{E}-01$ & 0.454 & $9.20 \mathrm{E}-03$ & $2.54 \mathrm{E}-02$ & 0.03456524 & $0.00 \mathrm{E}+00$ & $0.00 \mathrm{E}+00$ & 0 & 0.48856524 & \\
\hline 6042 & $8.62 \mathrm{E}-01$ & $1.30 \mathrm{E}+00$ & 2.162 & $1.06 \mathrm{E}-01$ & $1.27 \mathrm{E}-01$ & 0.233379 & $0.00 \mathrm{E}+00$ & $0.00 \mathrm{E}+00$ & 0 & 2.395379 & Outside of Earth berm \\
\hline 6047 & $9.94 \mathrm{E}-01$ & $1.64 \mathrm{E}+00$ & 2.634 & $2.00 \mathrm{E}-01$ & $2.25 \mathrm{E}-01$ & 0.42558 & $0.00 \mathrm{E}+00$ & $0.00 \mathrm{E}+00$ & 0 & 3.05958 & outside of Ring \\
\hline 6512 & $8.45 \mathrm{E}-01$ & $1.30 \mathrm{E}+00$ & 2.145 & 1.49E-01 & $3.00 \mathrm{E}-01$ & 0.449197 & $0.00 \mathrm{E}+00$ & $0.00 \mathrm{E}+00$ & 0 & 2.594197 & \\
\hline 7042 & $2.20 \mathrm{E}-01$ & 3.36E-01 & 0.556 & 3.57E-01 & $5.25 \mathrm{E}-01$ & 0.88128 & $0.00 \mathrm{E}+00$ & $0.00 \mathrm{E}+00$ & 0 & 1.43728 & \\
\hline 7047 & 4.10E-02 & 7.55E-02 & 0.1165 & $5.29 \mathrm{E}-01$ & 8.03E-01 & 1.331834 & $0.00 \mathrm{E}+00$ & $0.00 \mathrm{E}+00$ & 0 & 1.448334 & \\
\hline 7512 & $2.04 \mathrm{E}-02$ & $4.80 \mathrm{E}-02$ & 0.0684 & 4.16E-01 & $6.79 \mathrm{E}-01$ & 1.095261 & $0.00 \mathrm{E}+00$ & $0.00 \mathrm{E}+00$ & 0 & 1.163661 & \\
\hline 8042 & $5.26 \mathrm{E}-02$ & $7.38 \mathrm{E}-02$ & 0.1264 & $2.80 \mathrm{E}-01$ & 4.73E-01 & 0.752551 & $8.10 \mathrm{E}-03$ & $1.79 \mathrm{E}-02$ & 0.02596705 & 0.90491805 & \\
\hline 8047 & $3.29 \mathrm{E}-02$ & $5.95 \mathrm{E}-02$ & 0.0924 & 2.72E-01 & $5.10 \mathrm{E}-01$ & 0.782275 & 8.34E-02 & 1.65E-01 & 0.2488502 & 1.1235252 & \\
\hline 8512 & $1.25 \mathrm{E}-02$ & 3.54E-02 & 0.0479 & $2.09 \mathrm{E}-01$ & $2.69 \mathrm{E}-01$ & 0.478602 & $1.21 \mathrm{E}-01$ & 1.65E-01 & 0.286423 & $\underline{0.812925}$ & \\
\hline
\end{tabular}


TABLE 2 - ACTIVATION BY CELL IN CURIES

\begin{tabular}{|c|c|c|c|c|c|}
\hline Cell number Shutdown & $4 \mathrm{hrs}$ & 1 day & 7 days & 30 days & \multirow[t]{2}{*}{ Remarks } \\
\hline $102.202(-4)$ & $4.0(-7)$ & $4.0(-7)$ & $4.0(-7)$ & $4.0(-7)$ & \\
\hline $114.270(-1)$ & $1.821(-2)$ & $1.8(-2)$ & $1.655(-2)$ & $1.234(-2)$ & \multirow{3}{*}{$\begin{array}{l}\text { Primary Collimator } \\
\text { Cooling Water }\end{array}$} \\
\hline $121.027(0)$ & $4.249(-2)$ & $4.2(-2)$ & $3.884(-2)$ & $2.879(-2)$ & \\
\hline $138.55(-2)$ & $1.604(-2)$ & $1.604(-2)$ & $1.604(-2)$ & $1.604(-2)$ & \\
\hline $322.051(-4)$ & $1.562(-4)$ & $1.562(-4)$ & $1.562(-4)$ & $1.562(-4)$ & \multirow{4}{*}{ Tunnel Air } \\
\hline $342.423(-2)$ & $4.703(-4)$ & $4.703(-4)$ & $4.703(-4)$ & $4.703(-4)$ & \\
\hline 3003 3.296(-2) & $3.77(-3)$ & $3.547(-3)$ & $3.188(-3)$ & $2.149(-3)$ & \\
\hline $40657.058(-3)$ & $8.852(-5)$ & $8.852(-5)$ & $8.852(-5)$ & $8.852(-5)$ & \\
\hline $4583.683(-3)$ & $9.447(-11)$ & $9.447(-11)$ & & $1.992(-14)$ & \multirow{4}{*}{$\begin{array}{l}\text { Tunnel Cooling Water } \\
\text { (along inside wall } \\
\text { and at floor level) }\end{array}$} \\
\hline $4591.816(-2)$ & $9.101(-4)$ & $8.998(-4)$ & 8.322(-4) & $6.169(-4)$ & \\
\hline $4601.664(-2)$ & $1.06(-6)$ & $1.007(-7)$ & $1.007(-7)$ & $1.007(-7)$ & \\
\hline $4611.443(-2)$ & $1.516(-3)$ & $1.499(-3)$ & $1.387(-3)$ & $1.028(-3)$ & \\
\hline $4704.35(-4)$ & $1.0(-7)$ & $1.0(-7)$ & $1.0(-7)$ & $1.0(-7)$ & \multirow{5}{*}{$\begin{array}{l}\text { Tunnel Cooling Water } \\
\text { (along outside wall } \\
\text { and just below crane) }\end{array}$} \\
\hline $4712.629(-3)$ & $1.0(-7)$ & $1.0(-7)$ & $1.0(-7)$ & $1.0(-7)$ & \\
\hline $4726.018(-3)$ & $4.797(-7)$ & $4.797(-3)$ & $4.797(-7)$ & $4.797(-7)$ & \\
\hline $4734.192(-3)$ & $4.797(-7)$ & $4.797(-7)$ & $4.797(-7)$ & $4.797(-7)$ & \\
\hline $4747.007(-3)$ & $1.517(-3)$ & $1.517(-3)$ & $1.517(-3)$ & $1.517(-3)$ & \\
\hline $10486.78(-1)$ & $1.80(-1)$ & $9.871(-2)$ & $6.807(-2)$ & $5.647(-2)$ & \multirow{16}{*}{$\begin{array}{l}\text { First Doublet } \\
\text { Windings protruding } \\
\text { beyond magnet - } \\
\text { front and back }\end{array}$} \\
\hline $10496.031(-1)$ & $1.412(-1)$ & $6.645(-2)$ & $4.031(-2)$ & $3.379(-2)$ & \\
\hline $10506.315(-1)$ & $1.52(-1)$ & $9.1(-2)$ & $6.4(-2)$ & $5.096(-2)$ & \\
\hline $10517.081(-1)$ & $2.473(-1)$ & $1.593(-1)$ & $1.141(-1)$ & 8.693(-2) & \\
\hline $10534.840(-1)$ & $8.977(-2)$ & $3.393(-2)$ & $1.211(-2)$ & $8.363(-3)$ & \\
\hline $10544.812(-1)$ & $1.042(-1)$ & $5.454(-2)$ & $3.019(-2)$ & $2.275(-2)$ & \\
\hline $10554.411(-1)$ & $8.458(-2)$ & $4.63(-2)$ & $3.229(-2)$ & $2.755(-2)$ & \\
\hline $10565.039(-1)$ & $1.036(-1)$ & $5.8(-2)$ & $3.83(-2)$ & $3.18(-2)$ & \\
\hline $12486.311(-1)$ & $1.249(-1)$ & $5.789(-2)$ & $3.084(-2)$ & $2.595(-2)$ & \\
\hline $12495.366(-1)$ & $1.440(-1)$ & $6.340(-2)$ & $3.467(-2)$ & $2.75(-2)$ & \\
\hline $12506.657(-1)$ & $1.869(-1)$ & $8.932(-2)$ & $5.147(-2)$ & $4.087(-2)$ & \\
\hline $12515.494(-1)$ & $1.549(-1)$ & $1.104(-1)$ & $8.045(-2)$ & $6.172(-2)$ & \\
\hline $12535.172(-1)$ & $1.020(-1)$ & $5.933(-2)$ & $4.086(-2)$ & $3.355(-2)$ & \\
\hline $12545.196(-1)$ & $1.112(-1)$ & $5.729(-2)$ & $3.301(-2)$ & $2.194(-2)$ & \\
\hline $12554.826(-1)$ & $9.767(-2)$ & $4.293(-2)$ & $1.848(-2)$ & $1.519(-2)$ & \\
\hline $12564.585(-1)$ & $1.035(-1)$ & $5.084(-2)$ & $3.086(-2)$ & $2.633(-2)$ & \\
\hline
\end{tabular}


TABLE 3 - GAMMA-RAY SOURCE IN PHOTONS/SECOND

\begin{tabular}{|c|c|c|c|c|c|}
\hline Cell number Shutdown & $4 \mathrm{hrs}$ & 1 day & 7 days & 30 days & \multirow{5}{*}{$\begin{array}{l}\text { Primary Collimator } \\
\text { Cooling Water }\end{array}$} \\
\hline $103.427(7)$ & $4.412(2)$ & $4.412(2)$ & $4.412(2)$ & $4.412(2)$ & \\
\hline $113.971(10)$ & $8.851(5)$ & $5.737(3)$ & $5.737(3)$ & $5.737(3)$ & \\
\hline $128.517(10)$ & $2.404(6)$ & $1.685(4)$ & $1.685(4)$ & $1.685(4)$ & \\
\hline $136.371(9)$ & $1.846(3)$ & $1.764(3)$ & $1.764(3)$ & $1.764(3)$ & \\
\hline $326.832(6)$ & $1.72(5)$ & $1.72(5)$ & $1.72(5)$ & $1.72(5)$ & \multirow{4}{*}{ Tunnel Air } \\
\hline 34 1.808(9) & $5.18(5)$ & $5.18(5)$ & $5.18(5)$ & $5.18(5)$ & \\
\hline $30032.768(9)$ & $1.226(7)$ & $3.0(6)$ & $2.71(6)$ & $1.856(6)$ & \\
\hline $40655.021(8)$ & $9.748(4)$ & $9.748(4)$ & $9.748(4)$ & $9.748(4)$ & \\
\hline $4583.418(8)$ & $1.015(1)$ & $\sim$ & $\sim$ & $\sim$ & \multirow{4}{*}{$\begin{array}{l}\text { Tunnel Cooling Water } \\
\text { (along inside wall } \\
\text { and at floor level) }\end{array}$} \\
\hline $4591.707(9)$ & $3.164(4)$ & $2.206(2)$ & $2.206(2)$ & $2.206(2)$ & \\
\hline $4601.667(9)$ & $6.293(4)$ & $1.127(2)$ & $1.127(2)$ & $1.127(2)$ & \\
\hline $4616.015(8)$ & $1.103(2)$ & $1.103(2)$ & $1.103(2)$ & $1.103(2)$ & \\
\hline $4706.834(7)$ & $1.103(2)$ & $1.103(2)$ & $1.103(2)$ & $1.103(2)$ & \multirow{5}{*}{$\begin{array}{l}\text { Tunnel Cooling Water } \\
\text { (along outside wall } \\
\text { and just below crane) }\end{array}$} \\
\hline $4712.605(8)$ & $1.103(2)$ & $1.103(2)$ & $1.103(2)$ & $1.103(2)$ & \\
\hline $4725.487(8)$ & $3.141(4)$ & $\sim$ & $\sim$ & $\sim$ & \\
\hline $4733.511(8)$ & $3.141(4)$ & $\sim$ & $\sim$ & $\sim$ & \\
\hline $4744.710(8)$ & $6.305(4)$ & $2.207(2)$ & $2.207(2)$ & $2.207(2)$ & \\
\hline $10483.944(10)$ & $7.255(9)$ & $4.491(9)$ & $3.717(9)$ & $3.064(9)$ & \multirow{16}{*}{$\begin{array}{l}\text { First Doublet } \\
\text { Windings protruding } \\
\text { beyond magnet - } \\
\text { front and back }\end{array}$} \\
\hline $10494.330(10)$ & $5.972(9)$ & $3.179(9)$ & $2.525(9)$ & $2.1(9)$ & \\
\hline $10504.3(10)$ & $5.471(9)$ & $3.601(9)$ & $2.954(9)$ & $2.44(9)$ & \\
\hline $10514.314(10)$ & $1.207(10)$ & 8.824(9) & $6.822(9)$ & $4.749(9)$ & \\
\hline $10532.963(10)$ & $3.922(9)$ & $1.946(9)$ & $1.085(9)$ & $6.046(9)$ & \\
\hline $10543.05(10)$ & $3.225(9)$ & $1.742(9)$ & 1.197(9) & $9.572(8)$ & \\
\hline $10552.79(10)$ & $3.3(9)$ & $1.986(9)$ & $1.639(9)$ & $1.381(9)$ & \\
\hline $10563.019(10)$ & $4.079(9)$ & $2.691(9)$ & $2.194(9)$ & $1.79(9)$ & \\
\hline $12483.928(10)$ & $4.042(9)$ & $1.804(9)$ & $1.131(9)$ & $9.857(8)$ & \\
\hline $12493.0(10)$ & $6.014(9)$ & $3.19(9)$ & $2.38(9)$ & 1.511(9) & \\
\hline $12504.089(10)$ & $7.716(9)$ & 4.33(9) & $3.114(9)$ & $2.353(9)$ & \\
\hline $12513.921(10)$ & $6.678(9)$ & $5.624(9)$ & 4.392(9) & $3.06(9)$ & \\
\hline $12533.443(10)$ & $3.624(9)$ & $2.206(9)$ & $1.774(9)$ & $1.494(9)$ & \\
\hline $12543.368(10)$ & $5.332(9)$ & $3.253(9)$ & 1.973(9) & $1.034(9)$ & \\
\hline $12552.726(10)$ & $2.975(9)$ & $1.561(9)$ & $1.016(9)$ & $8.341(8)$ & \\
\hline $12562.567(10)$ & $3.86(9)$ & $2.157(9)$ & $1.683(9)$ & $1.419(9)$ & \\
\hline
\end{tabular}


TABLE 4 - ACTIVATION IN CURIES OF LONG LIVED ISOTOPES

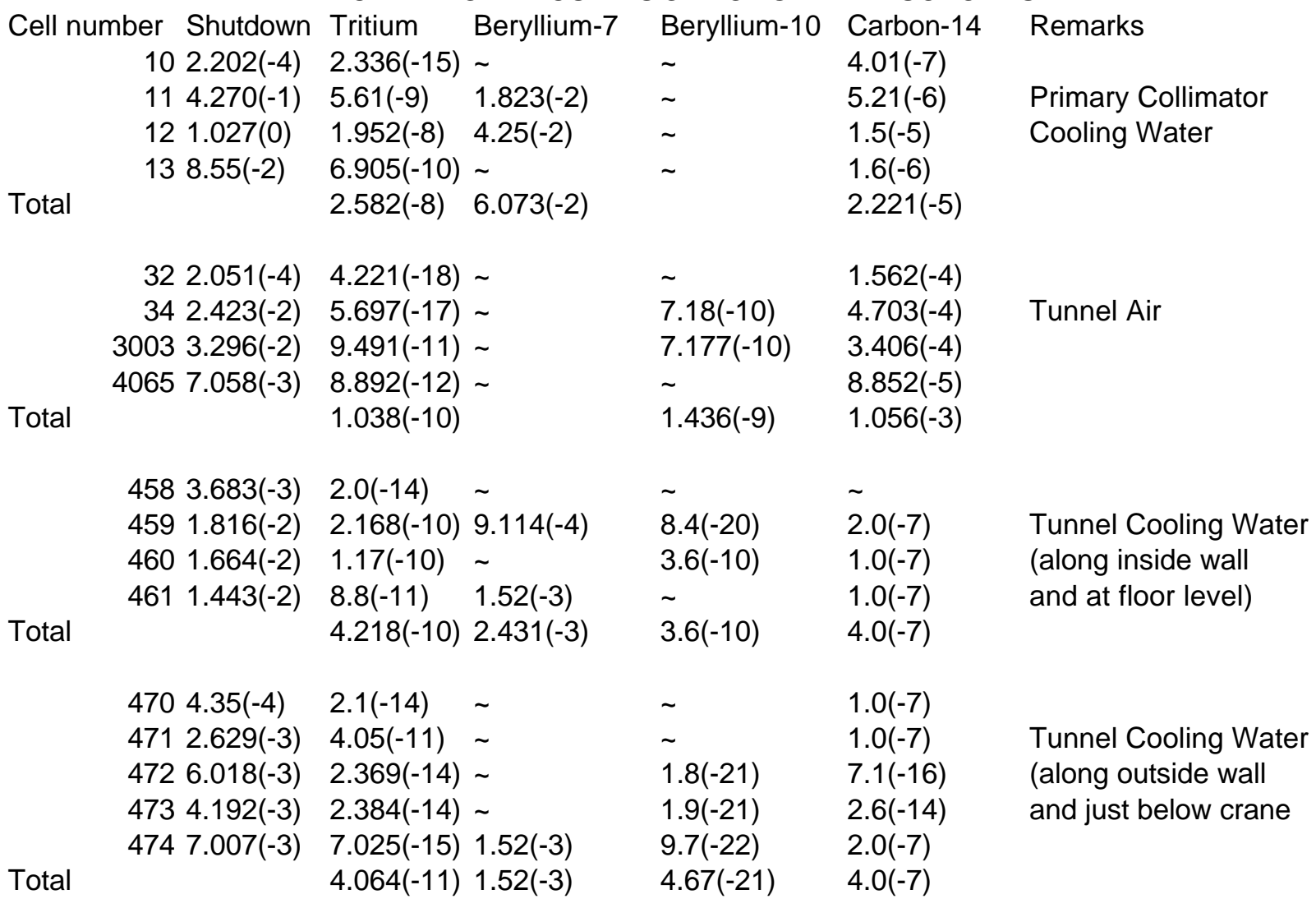



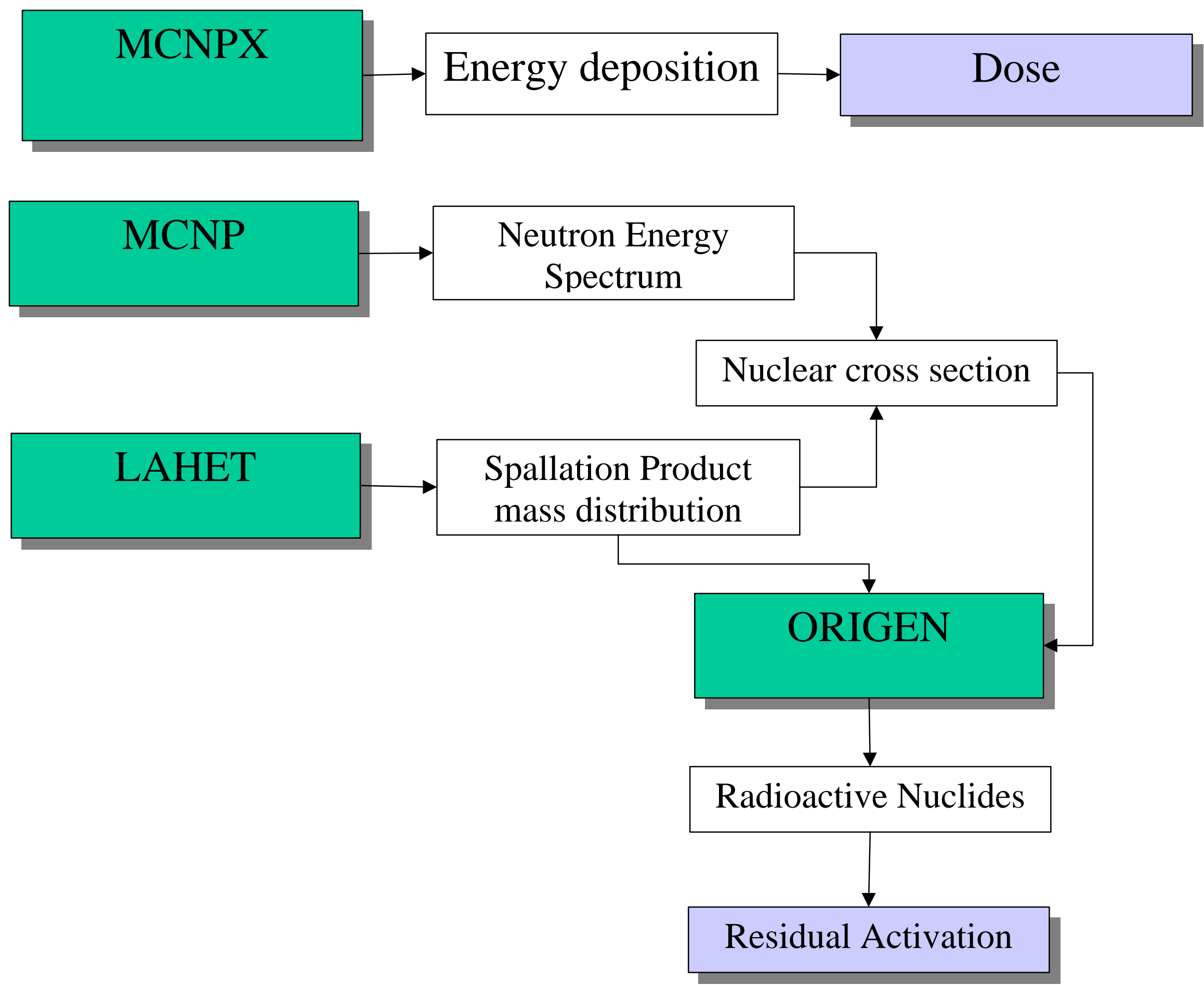


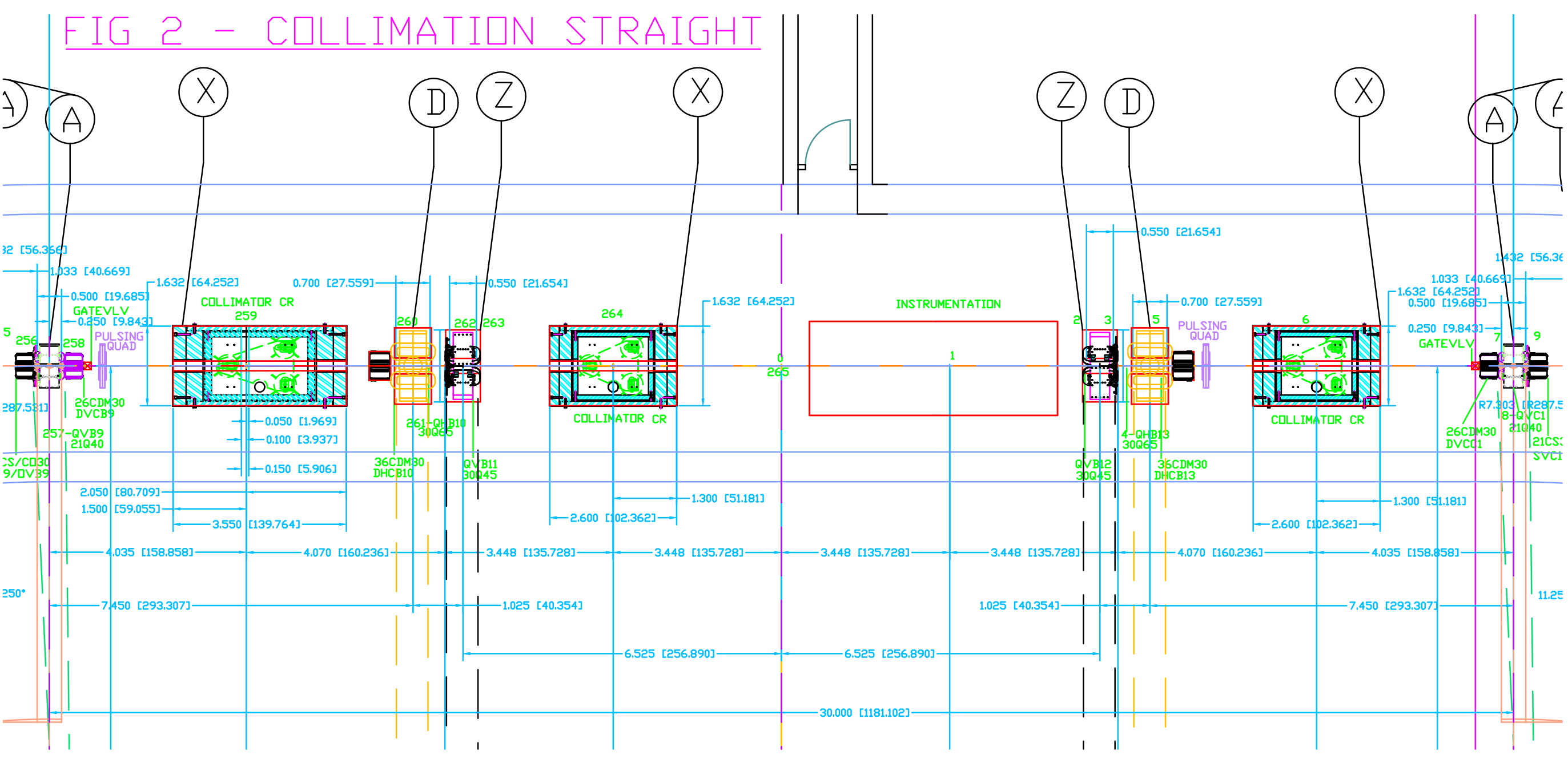




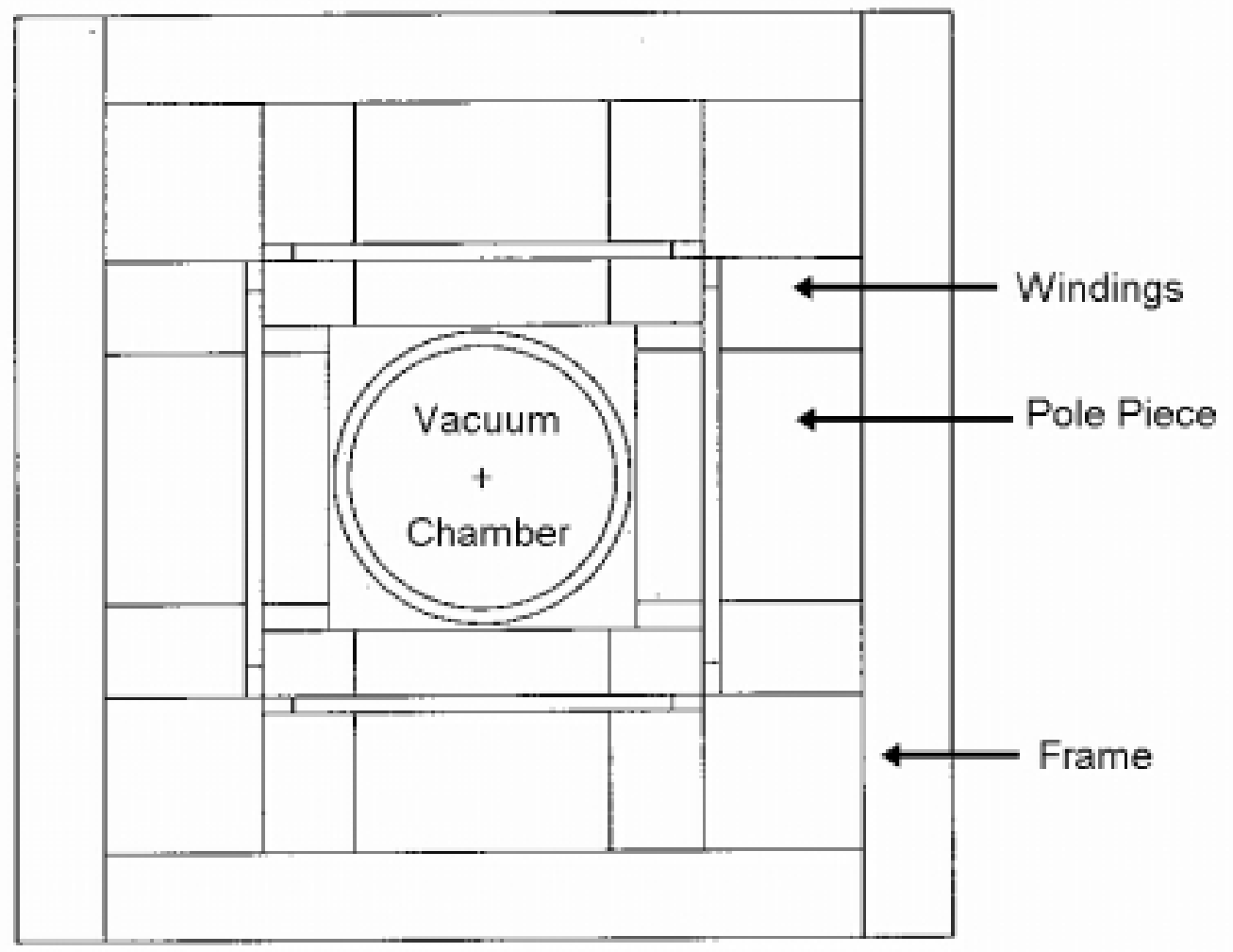

Figure 3: Cross Section Through Quadru-Pole Magnet

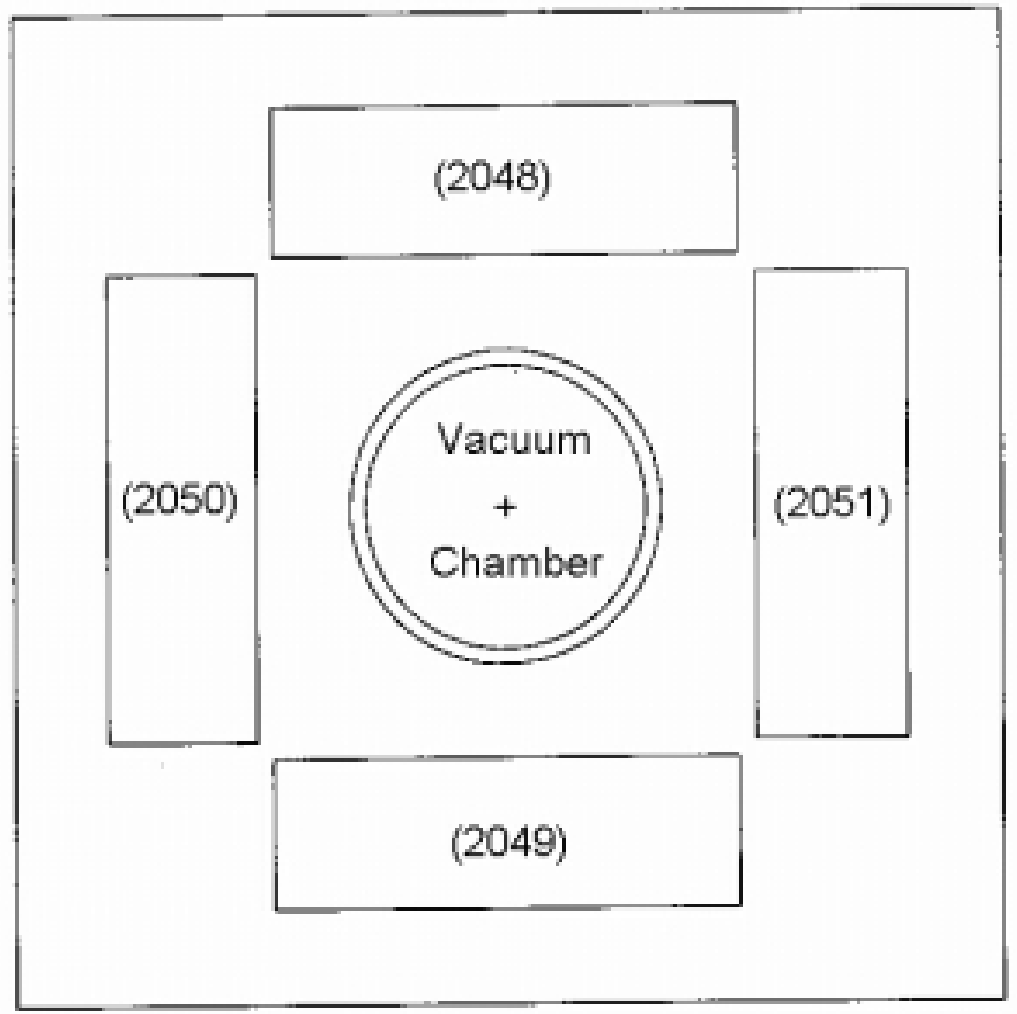

Figure 4: Cross Section Through Cells in Which Dose is Determined (First Quadru-Pole - Cell Number in Parenthesis) 


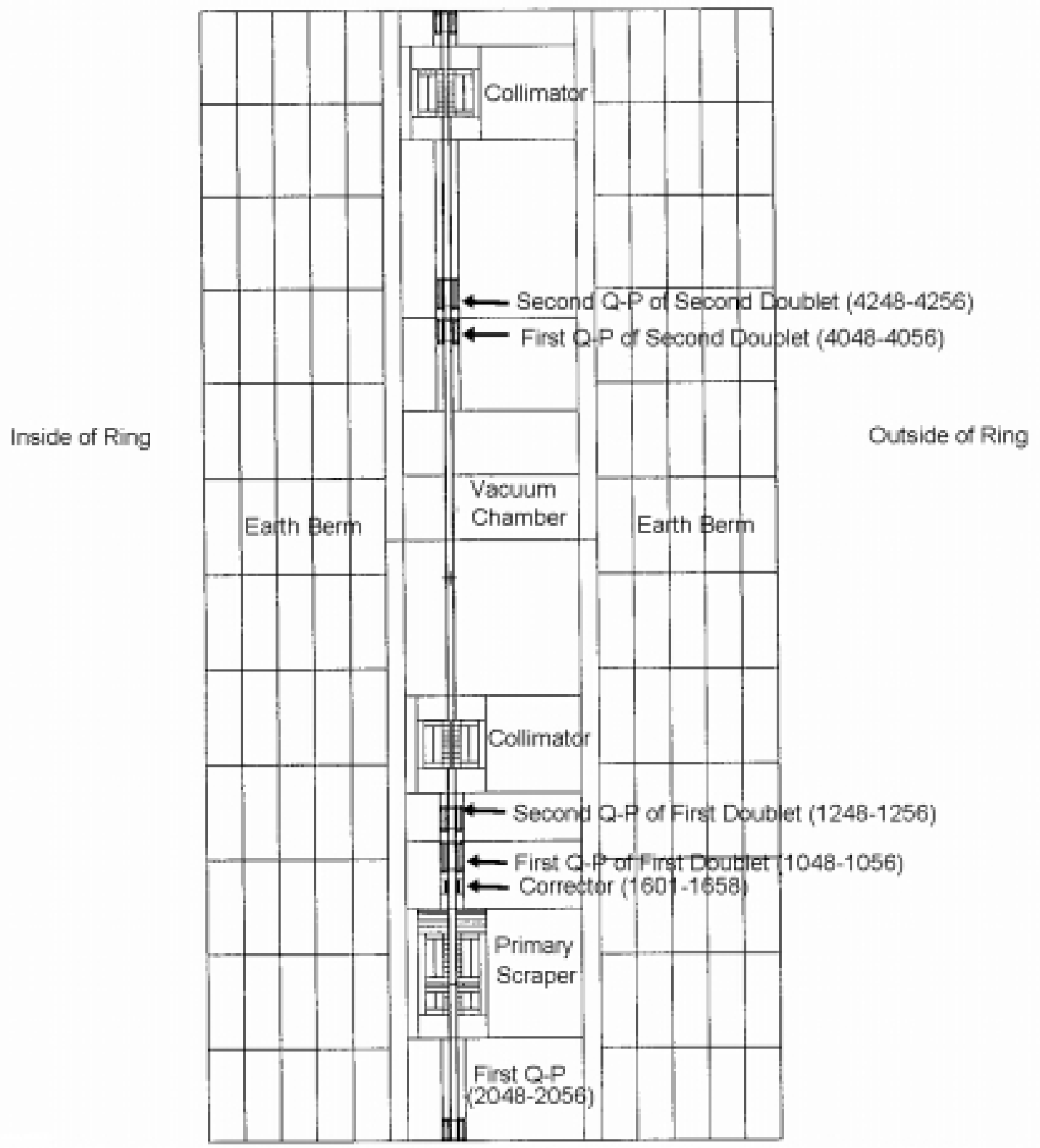

Figure 5: Longtitunal Section Along Collimation Straight of Ring at Level of Vacuum Chamber (Number in parenthesis correspond to magnet cell number used in tables) 


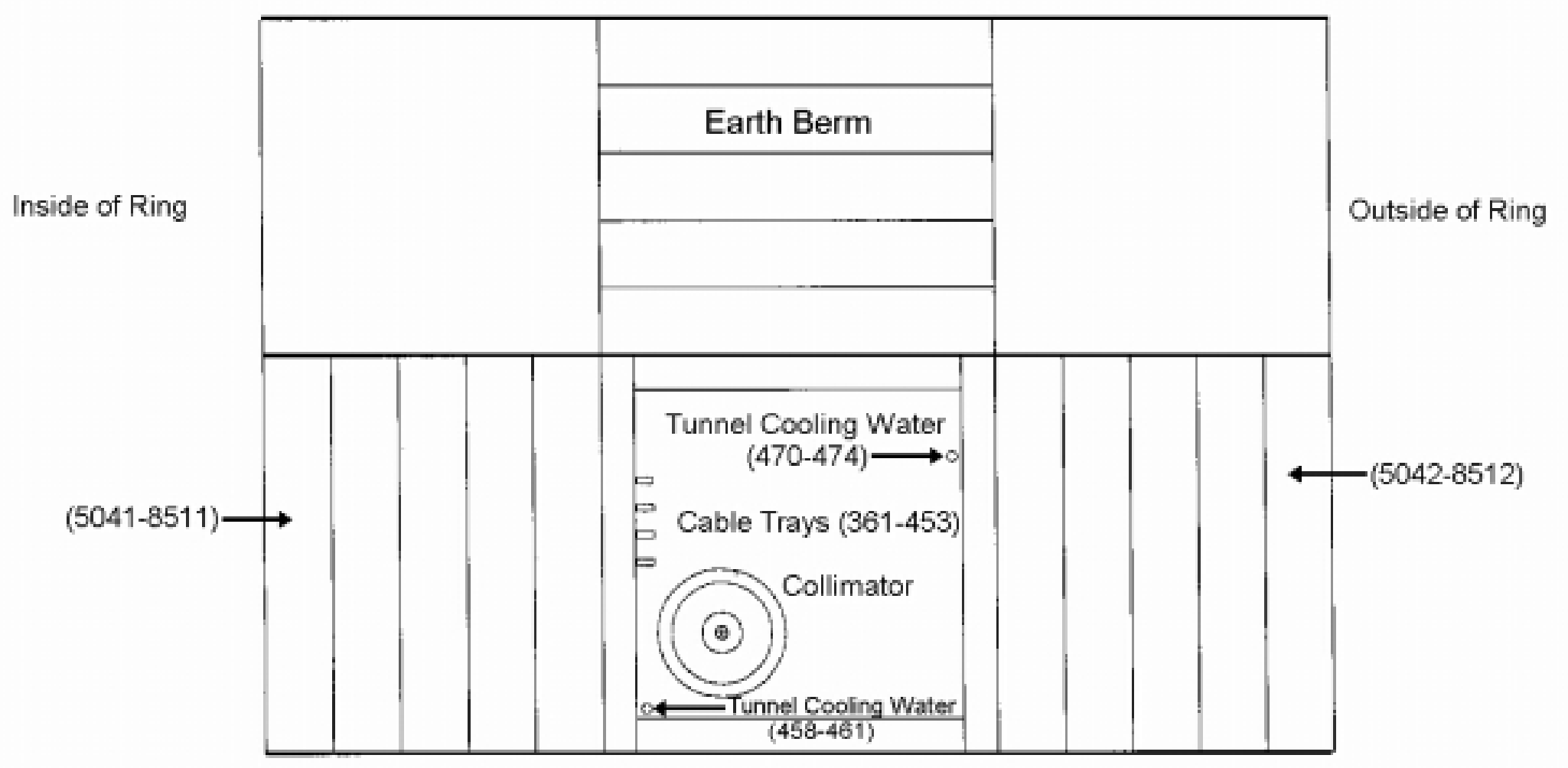

Figure 6: Cross Section Through Ring at Location of Primary Scraper (Numbers in parenthesis corespond to cell numbers used in tables) 


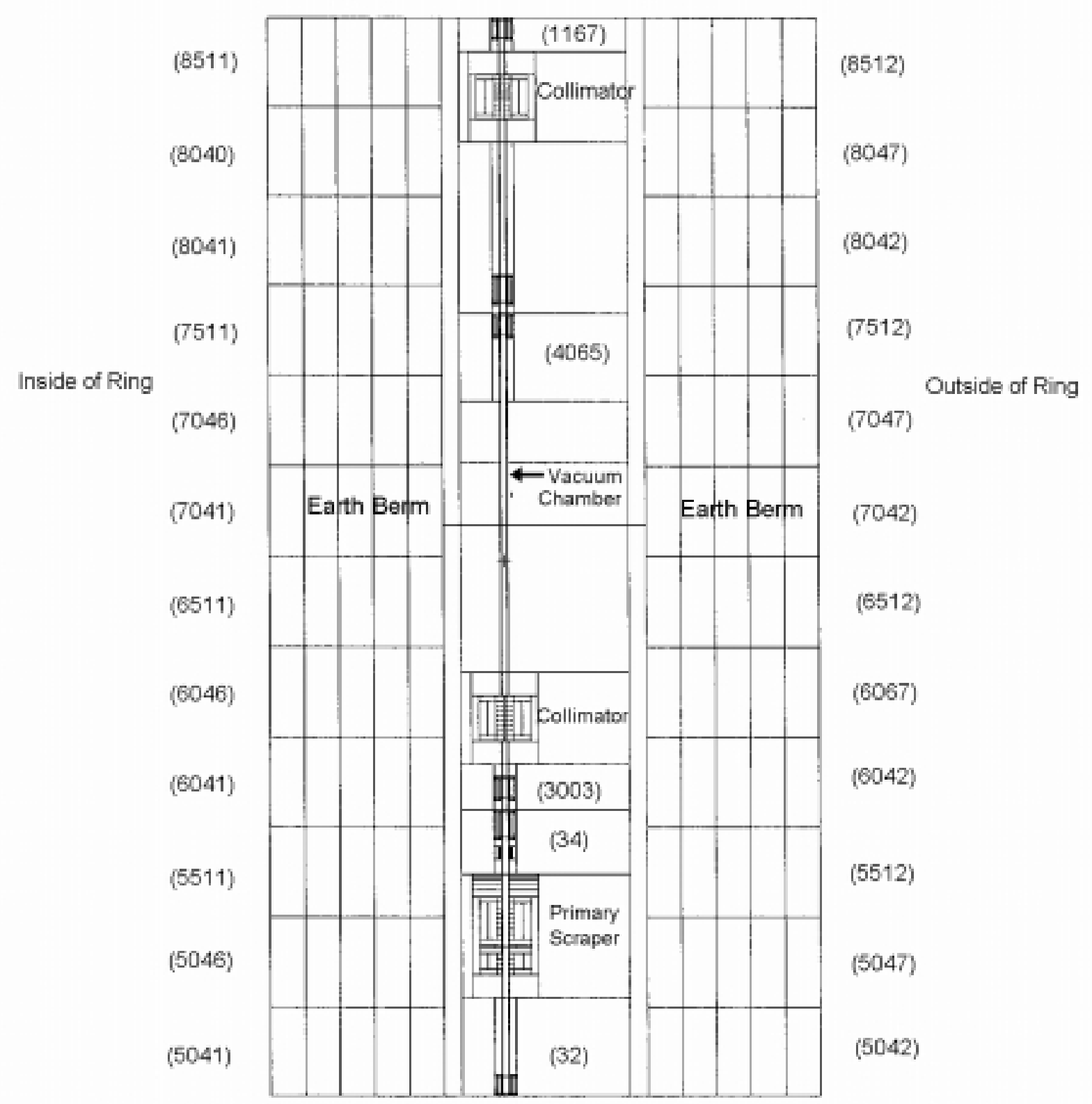

Figure 7: Longtitunal Section Along Collimation Straight of Ring at Level of Vacuum Chamber (Numbers in parenthesis correspond to earth berm and tunnel air cell numbers used in tables) 